\title{
Rare lichen taxa from Costa Rica
}

\section{Neuwirth $\mathbf{G}^{1}$ and Stocker-Wörgötter $\mathbf{E}^{\mathbf{2}}$}

\author{
${ }^{1}$ Rabenberg 18, A-4911 Tumeltsham, Austria; Email: gerh.neuwirth@tele2.at \\ ${ }^{2}$ Department Organismic Biology, University of Salzburg, Hellbrunner Str. 34, A-5020 Salzburg, Austria; Email: \\ Elfriede.stocker@sbg.ac.at
}

Neuwirth G, Stocker-Wörgötter E 2014 - Rare lichen taxa from Costa Rica. Mycosphere 5(6), 711718, Doi 10.5943/mycosphere/5/6/2

\begin{abstract}
The aim of this investigation is to document five remarkable lichen species which have been collected during several visits to Costa Rica by undertaking field trips to habitats of several vegetation zones. Pertusaria amnicola is new to the Neotropics and three species are new to Costa Rica (Enterographa sipmanii, Pertusaria borealis, Pertusaria torulosa).
\end{abstract}

Key words - lichenized ascomycota - Nearctica - Neotropics - new records

\section{Introduction:}

Central America forms a continuous land connection between two large continents, North America and South America, representing both a corridor for plants and fungi/lichens and also a barrier for marine organisms colonizing either the Caribbean (Gulf of Mexico) or the Pacific Ocean. Considering its position and varying climate, Costa Rica is especially rich in vegetation zones, e.g. savannahs, rivers and coastal lines with mangroves, tropical and dry forests, in-deciduous lowland forest, in-deciduous pre-montane forest, in-deciduous montane forests (1500-3000 m) and subalpine zone with high altitudes (3000 $\mathrm{m}$ and above the treeline), termed also as "paramo". For this reason, Costa Rica, has been recognized as a country with an immense variety.

The impressive lichen diversity as a consequence of extremely variable landscape topography from coastal lowland rainforests up to pre-montane, montane regions and subalpine zones at very high elevations have resulted in many new plant and lichen discoveries in Costa Rica. As a result of numerous different biotopes present, Costa Rica as a "small country" $\left(51.100 \mathrm{~km}^{2}\right)$ has offered researchers the opportunity to study all kinds of lichen specimens of the various vegetation zones in relatively short distances.

The aim of the present paper is to report on a number of species which have been overlooked and rarely collected in the Neotropics (South America) and also Costa Rica (Central America), which has been included in the biogeographic realms (Rich \& Rich 1983: Natural History of Costa Rica) of the Neotropica (South America) and Nearctica (considering the very high mountains and "Paramos", colonized by plant elements of North America). In contrast to newly described species which may have high interest, species recorded for a second and third time are rarely mentioned in literature, although they could be of high significance for our fragmentary knowledge of the respective ecosystems they belong to. 


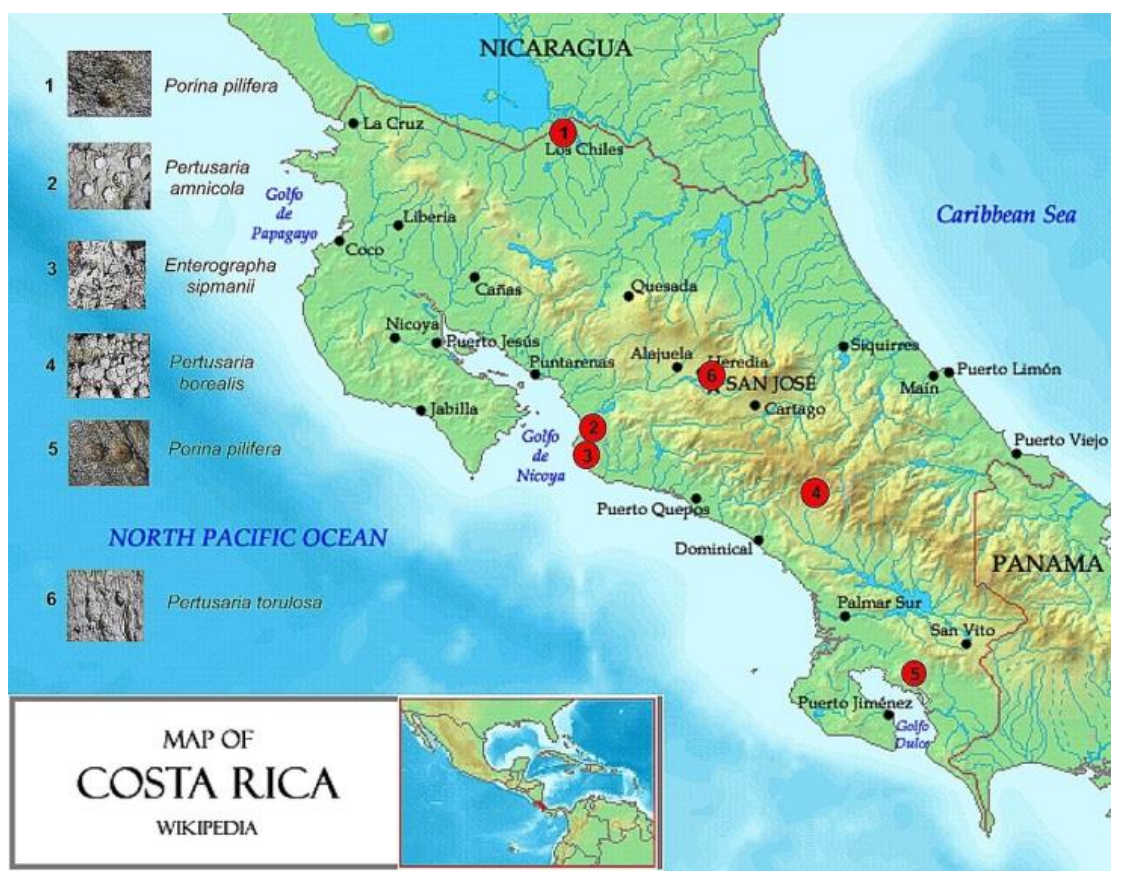

Fig. 1 - Collecting sites in Costa Rica. The Costa Rica map was provided by www.weltkarte.com/PUBLIC Domain Datei.

After a revision of our herbaria, we recognized some taxa which after determination turned out to be very rare or even new to the Neotropica and Nearctica of Costa Rica. The objective of this report is the presentation of some rediscovered and remarkable lichen species as a contribution to the knowledge of the lichen species inventory from Costa Rica, initiated by Lücking (2006).

\section{Material and Methods}

The specimens were collected during several visits in Costa Rica in the years 2008 and 2010 by the authors and deposited in their private herbaria.

Sections for anatomical investigations were mounted and examined at magnifications of x10-100 with a standard light microscope. Chemical examinations were made by the usual spot tests, investigations of secondary metabolites were performed by HPLC by the second author. Photographs were taken by the first author using a Canon EOS 600D-camera connected to a LM-Scope camera adapter.

\section{Results}

Pertusaria borealis Erichsen 1938.

Type - USA. Alaska: Kodiak Island, an Rinden, Hulten 5062 (UPS, lectotype), 5063 (HBG, syntype). Not seen.

Description - Thallus ash-grey, thin, distinct black prothallus, UV-; Medulla white; Soralia appearing as delimited, capitate and solitary fruit bodies up to a $1.4 \mathrm{~mm}$ diameter in our specimen, crowded and often touching each other; no apothecia.

Chemistry - Protocetraric acid, medulla $\mathrm{K}+\mathrm{y}$ turning red-brown, $\mathrm{P}+\mathrm{y}$ persistent. Substrate - on bark

Known distribution - restricted to the northern hemisphere (Dibben 1980). Asia: Russia; Europe: Austria, Scandinavia, Scotland, Spain; USA (Alaska, Viereck 8658 WIS; Port San Juan; Eyerdam 599 WIS) and Washington (Thomson 16205 WIS).

Locality - Prov. Cartago, Cordillera de Talamar, La Georgina E of Villa Mills. On bark of oak trees in a montane forest near Villa Mills, subalpine region, $2700 \mathrm{~m} ; 27.01 .2010$;

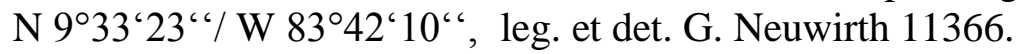

New to the Nearctica of Costa Rica. 


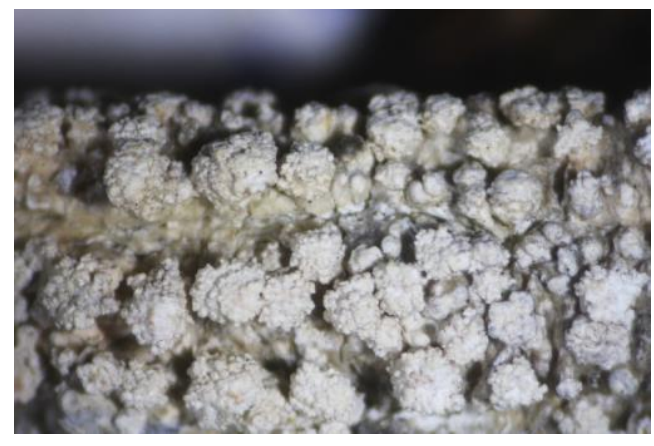

Fig. 2A - Pertusaria borealis, thallus with soralia up to $1.4 \mathrm{~mm}$ (Neuwirth 6682).

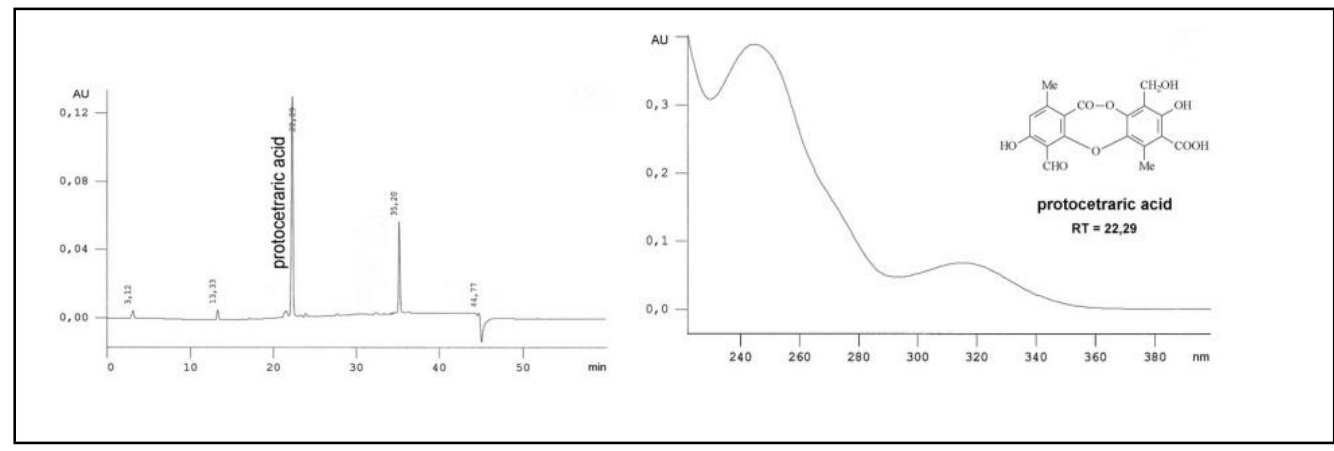

Fig. 2B - Chromatogram and UV-spectrum of protocetraric acid from Pertusaria borealis, obtained by HPLC analyses.

Pertusaria amnicola Elix \& A.W. Archer 1997.

Fig. 3A-F

The specimen is characterized by the following features:

Description - Thallus grey-greenish, smooth; often with hyphae growing on the surface. Apothecia $0.6-1.2 \mathrm{~mm}$ in diameter, disciform with distinct margins, prominent; E pithecium olive to brown, K+yellow; hymenium colorless, 120-180 $\mu \mathrm{m}$, Hypothecium brown, 50-90 $\mu \mathrm{m}$. Asci clavate, unitunicate, $150-180 \mu \mathrm{m}$; upper parts and tholi J+ blue. Paraphyses simple; Ascospores 2(1)/ ascus; 75-93 x 30-35 $\mu \mathrm{m}$.

Chemistry - spot tests: Cortex and medulla $\mathrm{K}+$ yellow turning red, $\mathrm{KC}-, \mathrm{C}-, \mathrm{P}+$ yellow, UV-. HPLC: Salazinic and consalazinic acid (depsidones; no depsides).

Substrate - on bark.

Locality - Punta Leona, Playa Blanca, 30.01. 2010; leg. E. Stocker-Wörgötter, det. J. Elix, G. Neuwirth. New to the Neotropics.

Known distribution - so far only known from Lord Howe Island in Australia (type locality, H. Streimann 56035, CANB).

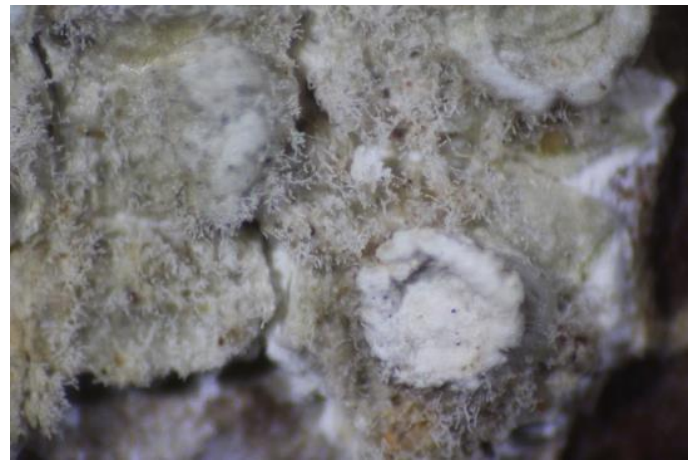

Fig. 3A - Pertusaria amnicola, thallus with hyphae growing from the surface (Stocker-Wörgötter 3872). Total width of photo $4.2 \mathrm{~mm}$. 


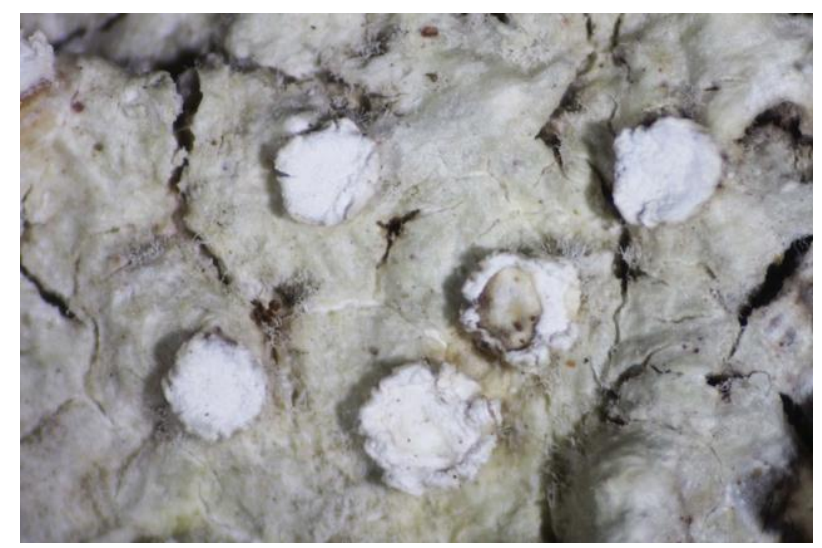

Fig. 3B - Pertusaria amnicola, thallus surface and apothecia 1.3-1.5 $\mathrm{mm}$ in diameter (StockerWörgötter 3872).

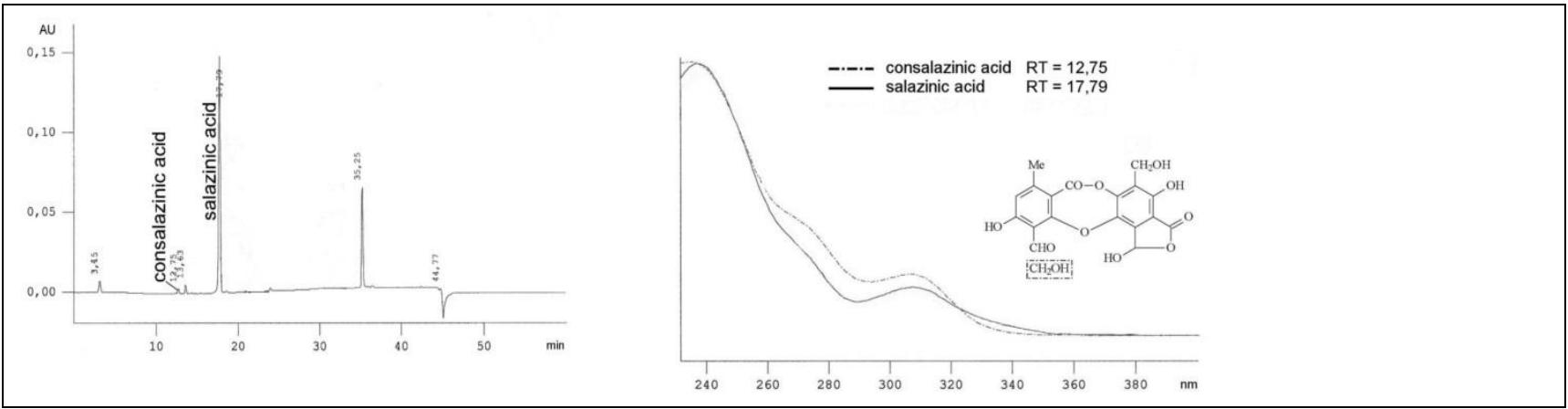

Fig. 3C - Chromatogram and UV-spectra of salazinic and consalazinic acids of Pertusaria amnicola, obtained by HPLC analyses.

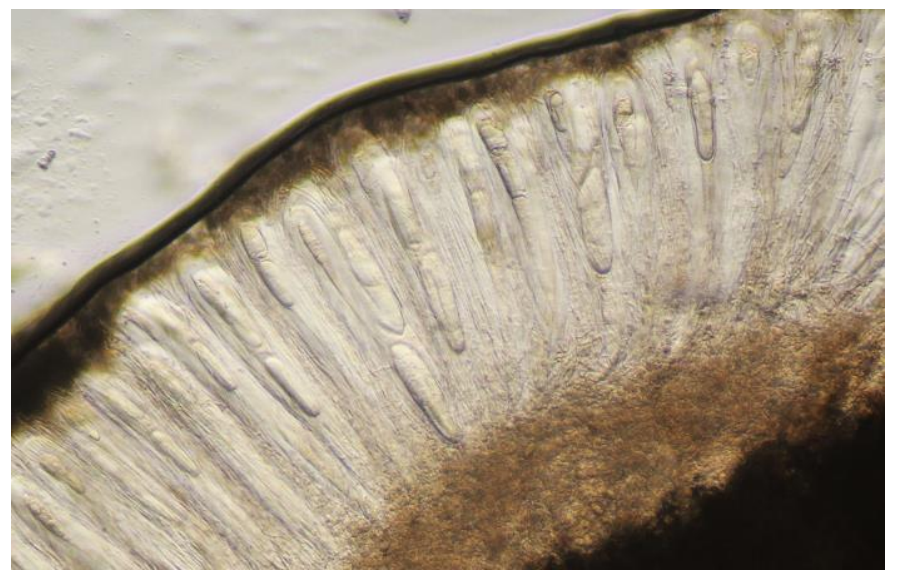

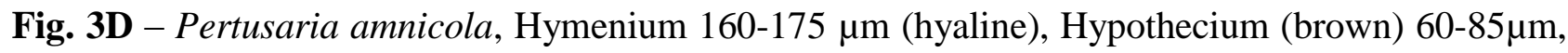
asci up to $150 \mu \mathrm{m}$.

Pertusaria torulosa Vain. 1915

Fig. 4A

Very rare species. We could only find one citation in Zahlbruckner Cat. Lich. Universalis 5: p. 245: Pertusaria torulosa Vain. In Annal. Acad. Sc. Fennic. ser. A, vol. VI, no. 7, 1915, p.

31. Insulae Antillarae, corticola.

These specimens might be the first records since Vainio one hundred years ago. Loc.: Cerro de la Muerte, Barva Volcano. 


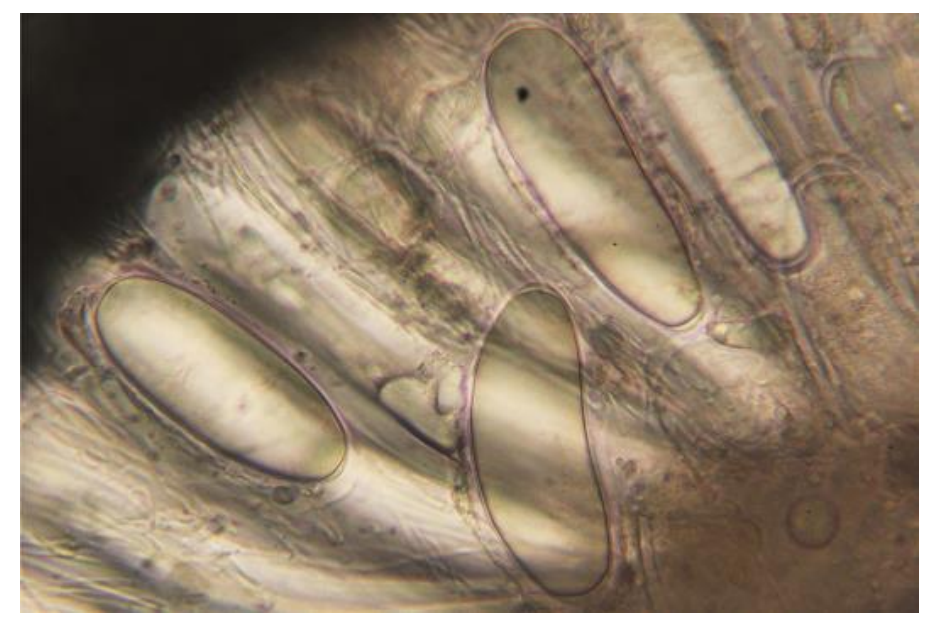

Fig. 3E - Pertusaria amnicola, ascospores 80-93 x 30-35 $\mu \mathrm{m}$.

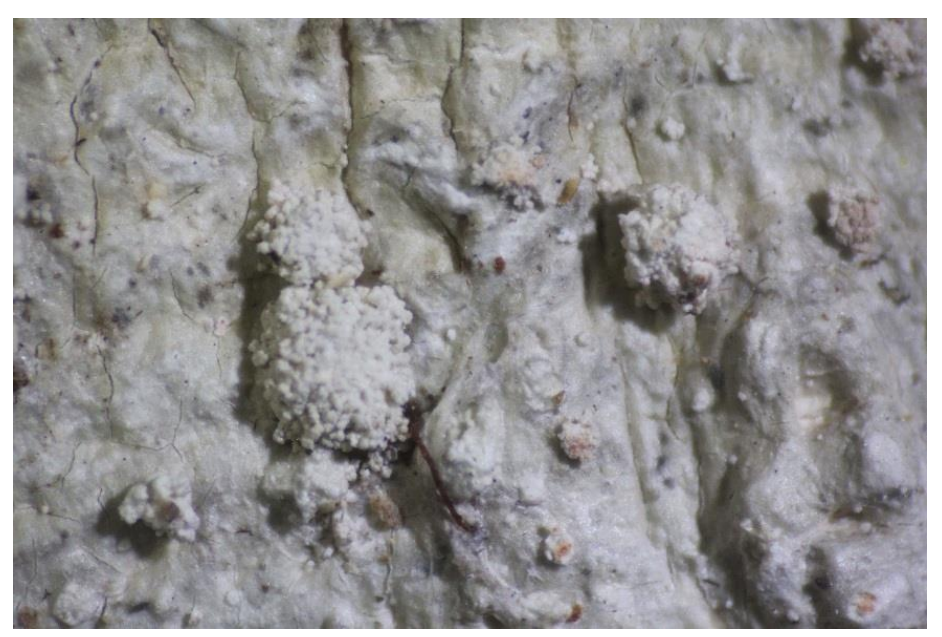

Fig. 4A - Pertusaria torulosa, soralia, section $10 \mathrm{~mm}$ wide.

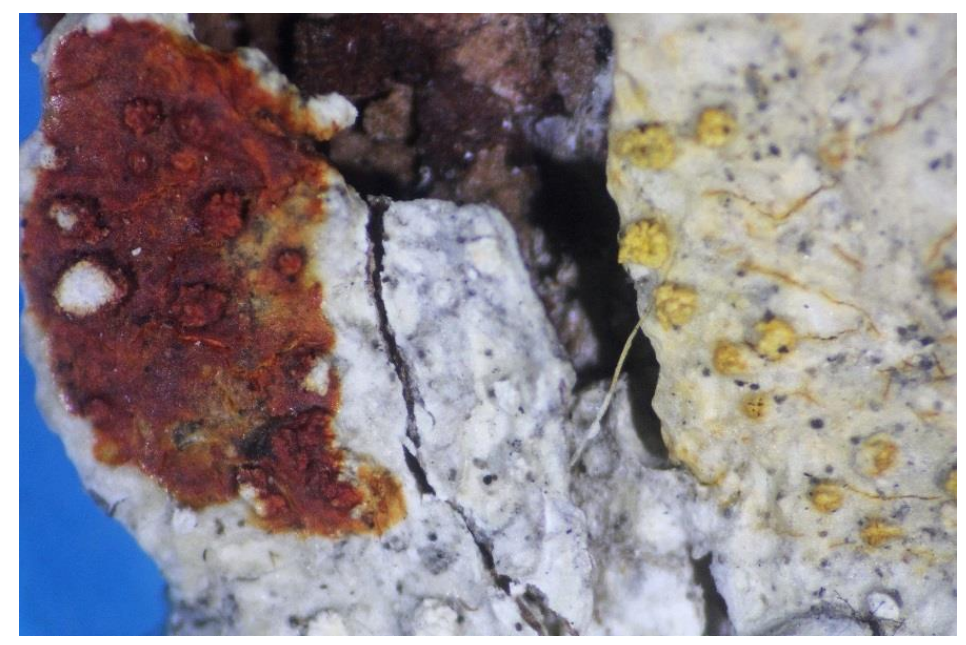

Fig. 4B - Pertusaria torulosa, spot tests: K+red, P+yellow, section $18 \mathrm{~mm}$ wide.

Description - Thallus grey, smooth, UV-, Soralia 0.8-1 mm (Fig. 4B).

Chemistry - Cortex and medulla $\mathrm{K}+$ yellow, turning red, forming red needles; P+y (Fig. 4C); norstictic acid.

Distribution - West Indies (Vainio 1915) and Costa Rica. 

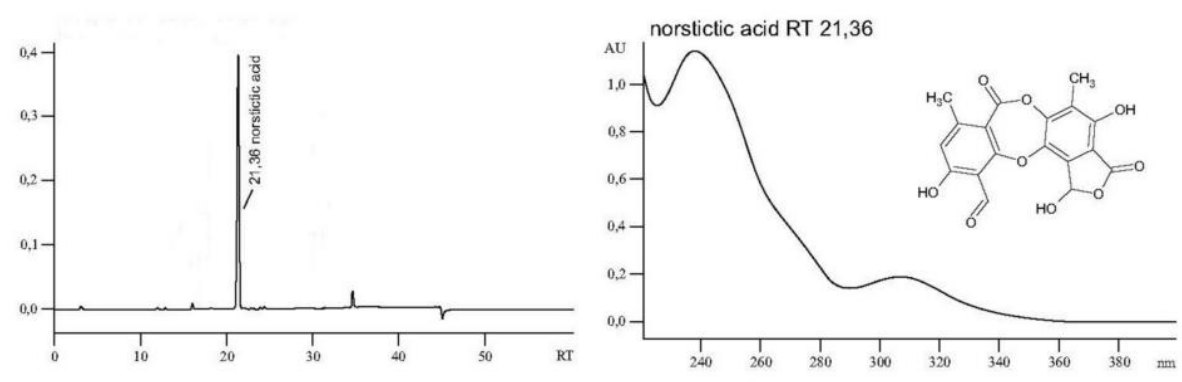

Fig. 4C - Chromatogram and UV-spectrum of norstictic acid of Pertusaria torulosa, obtained by HPLC analyses.

Enterographa sipmanii Sparrius 2004

Fig. 5

Third record world-wide.

Locality: Costa Rica, Punta Leon, Pacific coast, Playa Blanca; on shrubs; 30.01.2010; leg. E. Stocker-Wörgötter, det. L .B. Sparrius, G. Neuwirth.

Description - Thallus grey to whitish, UV-; with black, punctiform conodiomata spread all over the surface. Excipulum reddish (orange) brown, hymenium and hypothecium hyalin. Ascospores (5)-7-(9) $\mu \mathrm{m}$.

Chemistry - spot tests negative.

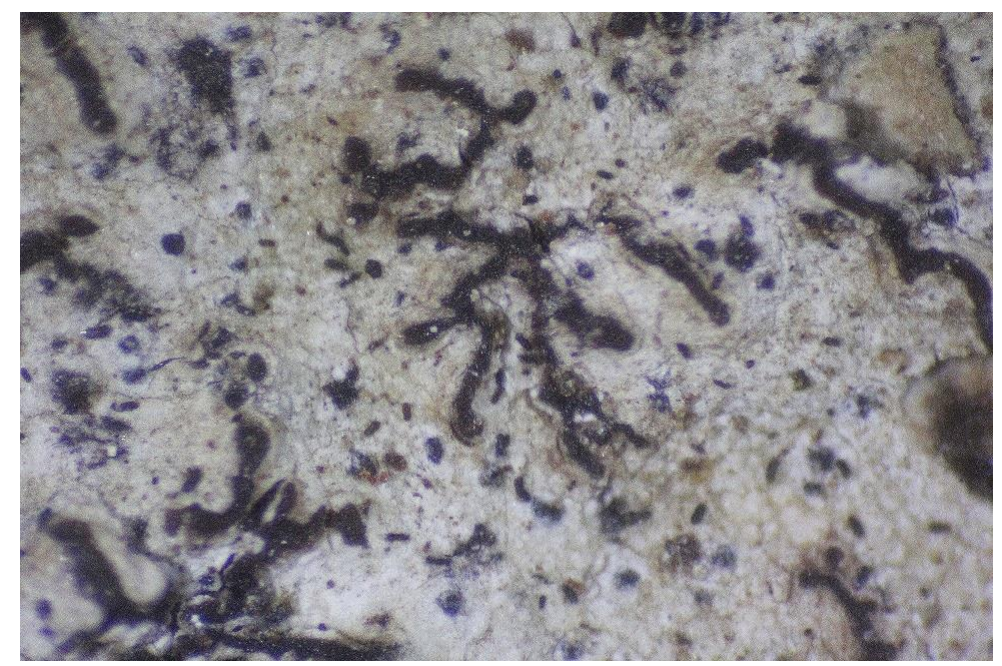

Fig. 5 - Enterographa sipmanii, habit. Lirellae $0.30-0.55 \mu \mathrm{m}$ long, 0.10-0.15 $\mu \mathrm{m}$ wide. Conidiomata black, punctiform (E. Stocker-Wörgötter 1226).

Known Distribution - Typus: French Guiana, Iles du Salut, $10 \mathrm{~km}$ off the coast N of Kourou, Ile. Royale, on Cocos at the coast; N $5^{\circ} 17^{\circ} / \mathrm{W} 52^{\circ} 35^{\circ}$, 5-50 m, 19.02.2033, Sipman 50651(B-holotypus, TLC).

Brazil, Pernambuco, Caruaru, Institoto Pernmbucano de Pesquisas Agropecuérias (IPA), S $8^{\circ} 17^{`}$ W $35^{\circ} 58^{‘ ،}$. Caatinga (open thornbush), 500-600 m; Caceres \& Lücking 00-0034b (F). (M.E. da Silva Cáceres 2007).

Porina pilifera Neuwirth 2006

Fig. 6

Three new habitats in Prov. Puntarenas, La Gamba, Esquinas rainforest, Fila-Trail, 104 m; N $08^{\circ} 41^{\prime} 55.8^{\prime \prime} / \mathrm{W} 83^{\circ} 12^{\prime} 17.5^{\prime \prime}$; 25.12.2008; Neuwirth 10119. Ibid.: $177 \mathrm{~m}, \mathrm{~N}$

$08^{\circ} 41^{\prime} 51.5^{\prime \prime} / \mathrm{W} 83^{\circ} 12^{\prime} 29.7^{\prime \prime}$; Neuwirth 10336, 10349; 25.12.2008. Ibid.: Waterfall-Trail, $164 \mathrm{~m} ; \mathrm{N}$ $08^{\circ} 41^{\prime} 43.3^{\prime \prime} / \mathrm{W} 83^{\circ} 12^{\prime} 25.6^{\prime \prime} ; 26.12 .2008$; Neuwirth 10236, 10244. 


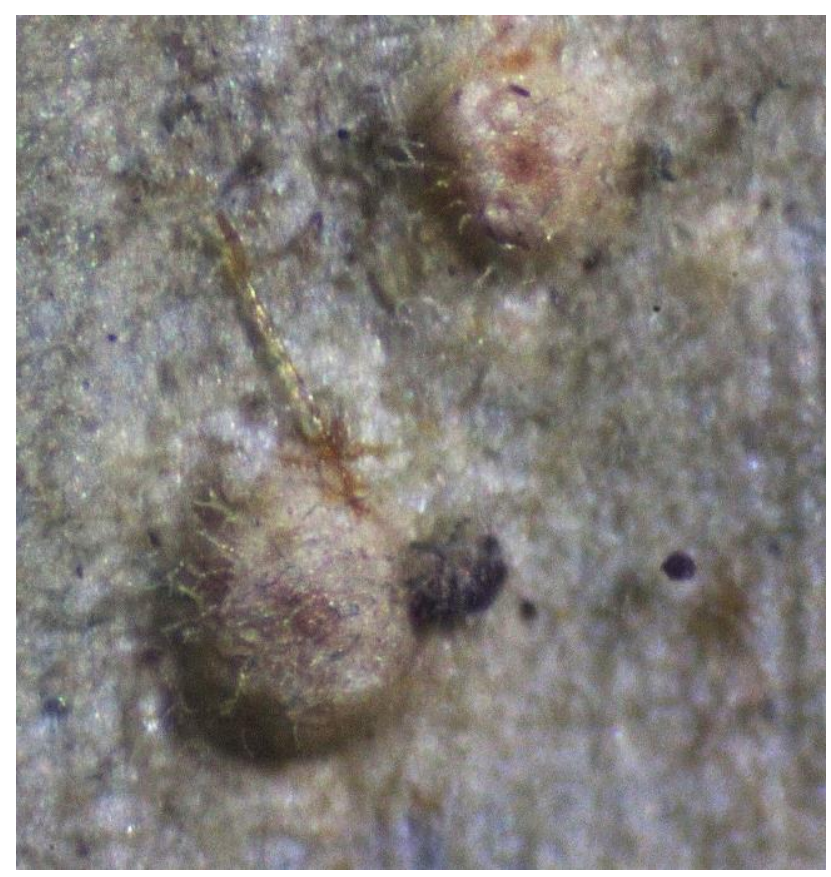

Fig. 6 - Porina pilifera, perithecia 0.3-0.4 mm in diameter (Neuwirth 10999b).

Prov. Alajuela, Llanura de los Guatusos near Los Chiles, gallery forest along Rio Frio; $35 \mathrm{~m}$, 10.01.2010; Neuwirth 10999b. Second locality world-wide.

Description - Thallus covered with a dense tomentum of thin hairs formed by mycobiont hyphae.

Perithecia hemisphaerical to subglobose, $0.2-0.4 \mathrm{~mm}$ in diameter, hidden in the thalline tomentum and easy to overlook.

Known distribution - The species prefers the upper surface of palm leaves in the understory of lowland rainforests at the Pacific coast of southern Costa Rica (Neuwirth G, Pfaller K. 2006).

Type: Costa Rica, Prov. Puntarenas, La Gamba, Esquinas rainforest, near waterfall on palm leaves, $70 \mathrm{~m}$ alt., 2 August 2004, G. Neuwirth 7036 (CR-holotype), WU-isotype; G. Neuwirth-paratypes 7046, 7469.

\section{Results and Discussion}

The collection of Pertusaria borealis in Costa Rica is the southernmost of all cited localities in the world and exceptional considering the high elevation of $2700 \mathrm{~m}$. The species predominantly occurs in the Boreal climatic zone in North America and Europe, except Spain (Mediterranean area) and seems to find comparable ecological conditions in montane regions to subalpine regions of the Neartica of Costa Rica .

The distribution of Pertusaria amnicola is described as a rare corticolous, endemic lichen species from Lord Howe Island (Australia) and therefore the second record world-wide and new to the Neotropics. The combination of salazinic and consalazinic acids was confusing, but J. Elix and A.W. Archer confirmed the identification of the specimen.

Pertusaria torulosa is characterised by the small soralia and the occurrence of norstictic acid. This extremely rare species was cited only one time. So the rediscovery in two habitats in Costa Rica could be of importance for lichenology.

Enterographa sipmanii shows ascomata embedded in stellate clusters and differs from $E$. quassiaecola in the 7-septate ascospores, narrower conidia, $\mathrm{J}+$ sky blue apothecium sections and the absence of $\mathrm{K}+$ yellow and $\mathrm{K}+$ green pigments in apothecia sections (Sparrius 2004).

The foliicolous species Porina pilifera was described as new to science by the first author in 2006. During a visit to the Esquinas Rainforest in the south of Costa Rica in 2010 the Porina species was collected again at three different localities in the same lowland rainforest living on palm 
leaves near the type locality, but had not been published up to the present. An important, additional record represents the specimen from 2010, which documents the presence of P. pilifera at a second locality along the Rio Frio in northern Costa Rica, although the species was supposed to be endemic in the Bosque Esquinas (Neuwirth \& Pfaller 2006).

\section{Acknowledgements}

Dr John Elix is warmly thanked for assistance in identifying and confirming of two Pertusaria species and Dr Laurens Sparrius for identifying the Enterographa. We also thank MINAE for providing the scientific passport No. 04393 (2010) and SINAC for the "Permiso de Exportacion"(2010). EST-W is very grateful to the Austrian Science Foundation (FWF) for support by the grants P 20887 and P 23570. InBio (Heredia, Costa Rica) and Giselle Timayo is thanked for organizing field trips and the invitation to the Research Labs (Workshop; February 2010).

\section{References}

Archer AW. 2012 - Pertusaria (Lichenised Ascomycota) in Australia. Australian Biological $\begin{array}{llllll}\text { Resources } & \text { Study, } & \text { Canberra. } & \text { Version } & 10 & \text { March }\end{array}$ http://www.anbg.gov.au/abrs/lichenlist/PERTUSARIA.html

Archer AW, Elix JA. 2013 - A Preliminary World-wide Key to the Lichen Genus Pertusaria. http://www.rbgssyd.nsw.gov.au/science/Plant_Diversity_research/Key_to Pertusaria

Da Silva Caceres ME. 2007 - Corticolous crustose and microfoliose lichens of northeastern Brazil. Libri Bot. Vol. 22, 221-168.

Dibben MJ. 1980 - The chemostystematics of the lichen genus Pertusaria in North America north of Mexico. Milwaukee Public Museum, publications in biology and geology, Nr 5, 1-162.

Lücking R, Aptroop A, Umana L, Chaves JL, Sipman HJM, Nelsen P. 2006 - A first assessment of the Ticolichen biodiversity inventory in Costa Rica: the genus Gyaldeopsis and its segregates (Ostropales: Gomphillaceae), with a world-wide key and name status checklist. The Lichenologist 38(2), 131-160.

Neuwirth G, Pfaller K. 2006 - Porina pilifera (Porinaceae), a new foliicolous lichen from Costa Rica (Central America). The Lichenologist 38(5), 417-420.

Rich PV, Rich TH. 1983 - The Central American Dispersal route: Biotic History and Paleogeography. In: Costa Rican Natural History, D. H. Jenzen (ed.): 12-34.

Sparrius LB. 2004 - A monograph of Enterographa and Sclerophyton. Biblioth. Lichenol. 89, 1141.

Zahlbruckner A. 1928 - Catalogus lichenum universalis, vol. 5: p 245. Leipzig: Gebrüder Bornträger. 